\title{
20. CRUISE LEG SUMMARY AND DISCUSSION
}

\author{
M. N. A. Peterson, N. T. Edgar, C. C. von der Borch \\ Scripps Institute of Oceanography, La Jolla, California \\ and \\ R. W. Rex \\ University of California, Riverside, California
}

\section{SITE SUMMARIES}

\section{Site 8}

Site 8 was selected in the extreme western North Atlantic, and it is positioned on a rise between the Hatteras and Sohm Abyssal Plains. If the concept of sea-floor spreading is correct, this location will permit coring of sediment and basement rock which possibly are the oldest underlying the North Atlantic Ocean. On the profiler records for this site, there are three acoustical reflectors which have been mapped in the western North Atlantic (Ewing and Ewing, 1962 and Ewing et al., 1966) and are referred to as Horizons A, $\beta$, and $B$. The objectives here were to sample: the prominent reflectors, the sediment directly overlying the basement and the basement rock. The intermediate sedimentary sections were to be spot cored. Technical malfunctions thwarted two attempts to achieve these objectives, and a total of only 29 feet (8.9 meters) of sediment was recovered.

Two holes were drilled at this location. Hole 8 penetrated the sea floor 564 feet (172 meters), and the hole was aborted without having encountered resistant layers. Two spot cores were cut in Miocene and Eocene radiolarian mud and ooze, which are generally structureless. At Hole 8A, coring continued in the section below the maximum penetration of Hole 8 , and progressed to 1,004 feet (306 meters) below the sea floor. Chert was sampled at approximately 935 feet (285 meters). This depth agrees well with the interpreted position of Horizon $\mathrm{A}$ at this site, assuming an average sediment velocity of $1.80 \mathrm{~km} / \mathrm{sec}$. The chert is a silicified radiolarian clay approximately 30 feet $(9.1$ meters) thick. Apparently, the chert sequence was penetrated, although the hole was abandoned before this conclusion could be confirmed.

\section{Site 9}

Site 9 is located on northeastern flank of the Bermuda Rise about 100 miles west of the Sohm Abyssal Plain. Here, profiler records differ markedly from those of Site 8. The basement trace is rough and Horizons A, $\beta$ and $B$ are not recorded in the overlying 2600 to 2800 feet (792 to 853 meters) of sediment. The upper portion of the section is acoustically laminated and is underlain by sediment which is acoustically transparent, except for a single weak reflector approximately 400 feet (121.9 meters) above basement. Initially, it was planned to continuously core the acoustically laminated sediments, the weak reflector and the sediment between this reflector and the basement. The acoustically transparent section was to be spot cored, and the basement was to be extensively sampled.

Hole 9 was aborted at 1613 feet (491.6 meters) below the sea floor due to technical difficulties. Continuous coring of the acoustically laminated sediment yielded very poor recovery and was abandoned after six attempts. An additional six cores were cut in the underlying acoustically transparent section, and 94 feet of sediment was recovered. In Hole 9A, continuous coring was initiated at a depth of 2226 feet $(678.6$ meters) below the sea floor. At 2738 feet $(834.5$ meters)-the maximum penetration of Hole $9 \mathrm{~A}$-igneous rock was sampled, which is considered to represent basement. Two main sediment varieties were encountered: an upper unit of 700 feet (213 meters) of calcareous and siliceous microfossil ooze, and a lower section of 2040 feet (622 meters) of non-calcareous sparsely fossiliferous zeolitic clay, rich in the zeolite phillipsite. The microfossil ooze ranges in age from Quaternary to Miocene. The oldest available date for the underlying clay is late Cretaceous, however, it should be noted that the lowest 200 feet ( 60 meters) of sediment are unfossiliferous. Samples of cherty radiolarian ooze of Eocene Age, comparable to that sampled at Site 8 , were collected from within the zeolite clay interval. The olive-gray color of the clay becomes increasingly red with depth in the lowest 60 meters ( 200 feet) to the basalt surface where it is a brick-red fissile shale containing abundant iron and other metal oxides. Botryoidal manganese concretions and a few chips of altered glassy basalt were recovered from the deepest sampled level.

\section{Site 10}

Site 10 is located in an area of low abyssal hills on the lower western flank of the Mid-Atlantic Ridge, and it was originally proposed as a member of a series of sites distributed across the Mid-Atlantic Ridge in order 
to test the concept of sea-floor spreading. The profiler records for this area indicate a sedimentary section that is essentially acoustically transparent except for a single strong reflector. The objectives here were to sample this reflector, the sediment directly overlying basement and the basement rock. Because the section proved to be of great biostratigraphic interest, more coring was undertaken than was originally planned. Twenty cores were cut, and 251 feet ( 79 meters) of sediment was recovered. At 1506 feet (459 meters) below the sea floor, basaltic basement rock was sampled.

The dominant lithology at this site is a foraminiferalnannofossil chalk ooze, ranging in age from Pliocene down to Upper Cretaceous (lower-middle Campanian). A thin zone of zeolitic red clay of Miocene Age occurs in upper sections of the hole. Cherty radiolarian mudstones of lower Eocene Age, similar lithologically to those occurring at Sites 8 and 9, were found in the dominantly calcareous ooze. Volcanic debris and wellformed dolomite rhombs about 12 microns in size are associated with the calcareous ooze in deeper sections of the hole-with both of the above components increasing in amount with depth. Near the bottom of the hole, dolomite rhombs increase substantially in abundance. Vesicular basalt was cored at the bottom of the hole at a level equivalent to the depth of the acoustical basement, as determined from seismic reflection profiles. A total of about 2.4 meters ( 8 feet) of basalt was cored and recovered, including a thin marble-like contact zone with overlying unconsolidated dolomitic calcareous ooze containing Cretaceous foraminifera. The upper most surface of the igneous rock in contact with the white marble has a chilled glassy margin about 5 millimeters in thickness. In view of the marble contact zone, at least at this upper level, the basalt is probably an intrusive sill; the igneous rock contains megascopic plagioclase crystals.

\section{Site 11}

Site 11 is located on a northwest trending plateau of the upper portion of the western flank of the MidAtlantic Ridge. Seismic reflection profiles show no reflectors in the sediment which fills this isolated basin. The primary objective here was to sample the sediment directly overlying the basement and the basement rock. Therefore, only a single shallow core was to be cut before drilling to a depth approximately 100 feet above basement where continuous coring would be initiated.

Recovery was very poor, and only 22 feet ( 7 meters) of sediment was obtained from nine attempts. However, smears of sediment found on the core barrel indicated that the entire sediment column is composed of foraminiferal-nannofossil chalk ooze ranging in age from Quaternary to Miocene. At 881 feet (268 meters) below the sea floor, one foot ( 25 centimeters) of basalt was cored. A layer of baked nannofossil ooze was found within the basalt. This layer was separated from the basalt by chilled glassy contact zones.

\section{Site 12}

Site 12 is located on approximately 2000 feet of sediment overlying the Cape Verde Basin. Six reflectors of variable prominence are visible on profiler records from this region. This site was chosen to provide a biostratigraphic reference section; and, originally, the entire sediment column was to be continuously cored. Because of time restrictions and the possible presence of chert as indicated by the profiler records, only the upper portion of the sediment column was available for coring. In an attempt to insure complete recovery, five holes were drilled at this site. The depth of the deepest hole is 218 meters ( 717 feet) and a total of 72 meters (236 feet) of sediment was recovered from 24 attempts.

Sediments consist of foraminiferal-nannofossil chalk ooze of Quaternary to Pliocene Age in the upper 42 meters (137 feet) of section. Below this depth poorly fossiliferous zeolitic clay, similar to that cored at Site 9, dominates the lithology. In the case of Site 12 , the zeolites are associated with much volcanogenic material, including disseminated volcanic debris and discrete ash layers. Shards and de-vitrified shards are commonly associated with the zeolite mineral, phillipsite, and with montmorillonite and attapulgite (palygorskite). Some sections of this sediment exhibit thixotropic properties, possibly due to the presence of montmorillonite and attapulgite. Small, clear feldspar crystals of possible volcanic origin occur disseminated throughout the sediment as well as in small pockets. At a depth of 162 meters (530 feet), localized radiolarian-bearing Eocene sediments occur within the nonfossiliferous clay and zeolite sequence, associated with thin stringers of radiolarian chert of the same age, similar in both lithology and age to cherts cored in western North Atlantic sites. Below radiolarian-bearing sediments, zeolitic clay again dominates the lithology down to the bottom of the hole. Drilling ceased when an unsampled hard layer destroyed the bit. Overlying this bed a thin layer of dolomite silt was sampled containing an estimated 50 per cent by weight of 50-micron dolomite rhombs. At this site the recovery of core was greatly increased by the use of a plastic sleeve core-retaining device, which has since been used with great success whenever soft sediment was being cored.

\section{SYNTHESIS AND DISCUSSION}

\section{Regional Summary}

Two of the five sites (10 and 11) drilled on Leg 2 are located on the Mid-Atlantic Ridge and the remaining three (Sites 8, 9 and 12) are in the deep basins. The 
lithologic relationships among the Leg 2 sites is demonstrated diagrammatically in Figure 1.

The ridge sites are characterized by a uniform mineral composition of biogenic calcium carbonate throughout the hole. No detrital minerals were noted although kaolinite and quartz are common in the Miocene sediments of Site 10. The variety of sediments recovered from the three basin sites on Leg 2 suggests that the patterns of sedimentation and diagenesis may be considerably more complicated in the Atlantic than was previously anticipated. The dominant sediments sampled at Site 8 are Radiolaria-rich montmorillonite and kaolinite clays. At Site 9 montmorillonite and kaolinite typify the post-Eocene sediments, and cristobalite and kaolinite characterize the pre-Oligocene section. On the eastern side of the Mid-Atlantic Ridge (Site 12) the dominant clays are palygorskite (attapulgite) and sepiolite.

Figure 1 shows the relationship between the occurrence of calcareous sediments and depth at all of the sites on Leg 2. Calcareous microfossils are present (Vema piston cores) in the near-surface sediments at all three basin sites, even though Site 8 is below the present depth of calcium carbonate compensation ( 4900-5000 meters) in the North Atlantic (Berger, in preparation). Substantial quantities of calcareous sediments lie within the sedimentary column at Sites 8,9 and 10 at about 5150 meters below sea level. Also of interest is the presence of non-calcareous clay at Site 12, which is considerably shallower than the present depth of calcium carbonate compensation and shallower than calcareous sediments of the same age at Site 10. From this relationship one may conclude the following: the depth of compensation differed greatly within the Atlantic Ocean during the Tertiary, the eastern Atlantic surface waters did not support high calcareous organic productivity, or there has been substantial vertical motion of the sea floor.

Horizon A in the area investigated is believed to correspond to a ubiquitous chert layer associated with radiolarian-rich Eocene sediments. Eocene cherts were recovered at all basin sites on both sides of the Atlantic Ocean and on the Mid-Atlantic Ridge where sediments as old as Eocene exist.

The oldest dated sediments recovered on this leg are of late Cretaceous Age. Penetration and recovery of ancient basin samples was hampered by the presence of chert. Cretaceous sediments sampled on the MidAtlantic Ridge are calcareous, but those of the same age in the basin are dominantly deep-sea clays.

Igneous rocks, typical oceanic tholeiite basalts and diabases were recovered from three sites. The texture, high carbonate content and sediment contact suggests that they were emplaced as sills rather than flows. In general, the rock was deeply "weathered" or altered. These sills or flows correspond in depth to the acoustic basement.

Based on the paleontologic age of the sediments overlying the igneous rock, the sea floor in the North Atlantic at about $30^{\circ} \mathrm{N}$ has been spreading at the rate of about 1.2 centimeters a year since the earliest Campanian (Late Cretaceous).

\section{Sedimentology}

As a result of ship-board observations and shore laboratory work-mainly X-ray mineralogy (see Chapter 11)various sediments and rock types from Leg 2 were identified. These are listed below in approximate order of abundance:

Biogenic Pelagic Sediments
Nannoplankton and foraminiferal oozes
Radiolarian oozes
Volcanogenic Sediments
Palygorskite-sepiolite clays
Montmorillonitic clays
Ash beds and altered tuffs
Cristobalite-bearing sediments
Deep-Sea Clays
Red and brown clays
Terrigenous Sediments
Kaolinitic clays
Channel sands
Silty clays and fine sands, graded in part
Indurated Sediments
Radiolarian cherts
Silicified quartz silts
Authigenic Carbonates
Dolomite
Rhodochrosite
Siderite

These sections will be summarized and discussed in order below with an emphasis on sediment and rock mineralogy and possible genesis. A more comprehensive discussion of the mineralogy will be found in Chapter 11 .

\section{Nannoplankton and Foraminiferal Oozes}

Most of the calcareous pelagic oozes recovered during Leg 2 drilling are mixtures of foraminifera and calcareous nannoplankton. All gradations exist from pure calcareous oozes (chalks) to marls containing significant 


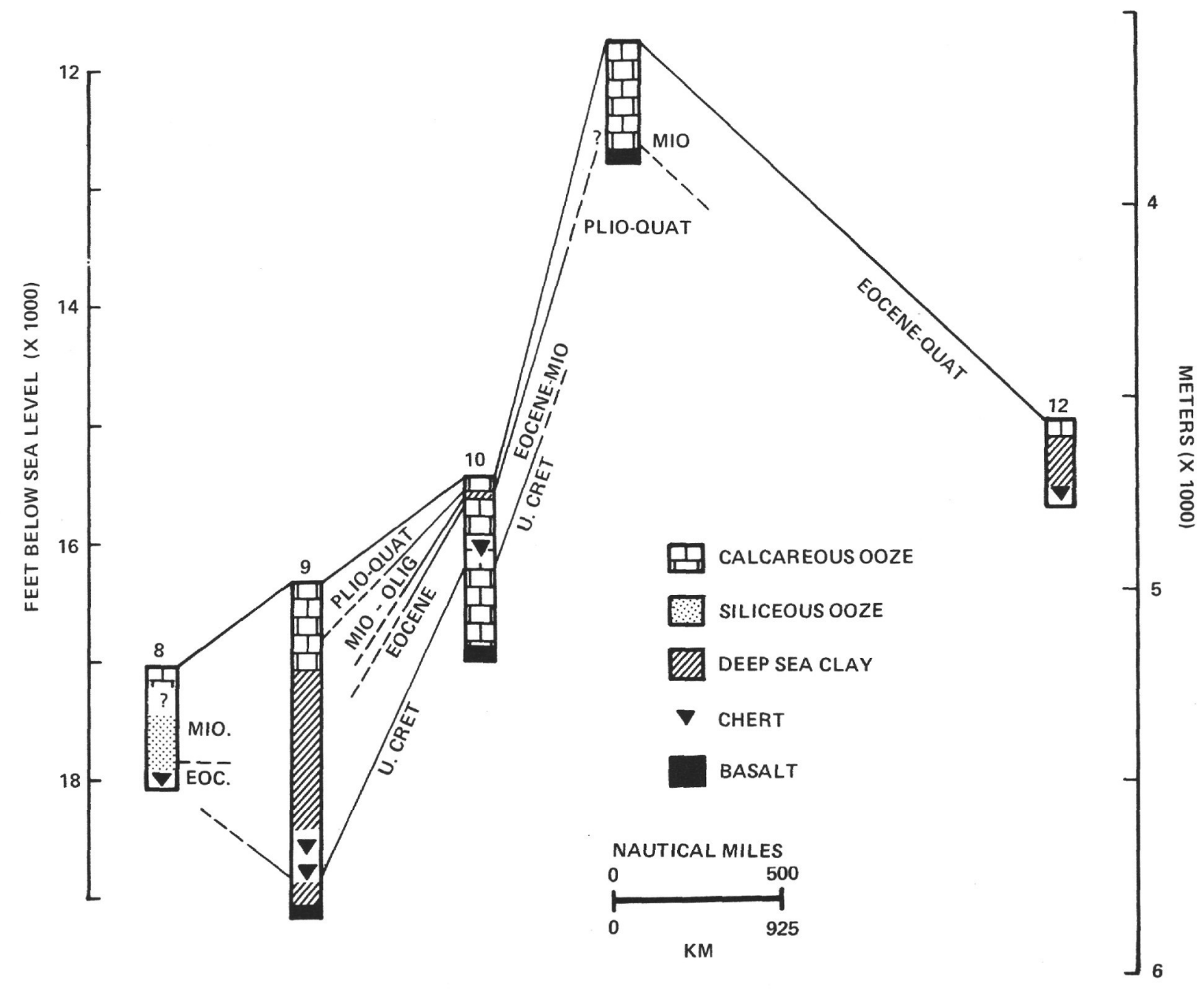

Figure 1. Correlation between sites drilled on Leg 2 of the Deep Sea Drilling Project. 
contaminants of volcanogenic and terrigenous clay minerals. Some of the calcareous oozes contain admixtures of siliceous microfossils which, in some cases, may have resulted from coring contamination. Interbedded calcareous oozes and clays occur in some instances, which are suggestive of fluctuations in the physical, chemical and biologic environments of the ocean.

Calcareous oozes are conspicuously absent from samples taken at Site 8, except for minor occurrences at upper levels of the sediment column. It appears that the sediment-water interface has been below the carbonate compensation depth at least since the Eocene, the age of the deepest sampled sediments.

In intermediate water depths, such as on the Bermuda Rise (Site 9), calcareous oozes predominate in the Miocene and Pliocene sediments but grade down to nonfossiliferous clays. This relationship could be the result of: a tectonic uplift of the rise during deposition to a depth shallower than the compensation depth; raising of the ocean floor by sedimentation to above the compensation depth; a major change in the depth of compensation; or limited organic productivity. The lack of siliceous organisms suggest the latter. A comparable situation exists at Site 12, except that the transition from calcareous to non-calcareous sediment occurs within a 2-meter interval.

Calcareous oozes predominate in all shallower holes, such as at Sites 10 and 11 on the western flank of the Mid-Atlantic Ridge. Site 10 has an essentially complete section of calcareous ooze which ranges in age from lower to middle Campanian to Quaternary. An exception at this site is a relatively thin deep-sea zeolitic clay of Miocene Age which is intercalated with the main units of calcareous ooze. Sediment at Site 11, near the Ridge crest, is entirely composed of chalk ooze containing foraminifera and nannoplankton, ranging in age from Miocene to Quaternary.

\section{Radiolarian Oozes}

Siliceous organic oozes-mainly radiolarian oozes-and muds occur principally at Site 8 in relatively deep water on the small rise between the Sohm and Hatteras Abyssal Plains. At this site, the siliceous fossils range in age from at least Eocene to upper-middle Miocene. Significant amounts of terrigenous clay and silt are commonly combined with this siliceous organic material, thus the term siliceous mud is more appropriate in most cases. Terrigenous admixtures probably originated on nearby continental North America.

At Sites 8, 9, 10 and 12, whenever Eocene cherty material was encountered by the drill, radiolarian oozes occur. These oozes appear to be directly associated with the chert horizons. In all of the above sites, excepting Site 8 , siliceous fossils appear to be unimportant in zones other than those associated with cherts which suggests that a period of siliceous organic productivity occurred over much of the North Atlantic Ocean.

\section{Palygorskite-Sepiolite Clays}

Based on the X-ray mineralogy of Rex (Chapter 11), the nonfossiliferous section of clays encountered at Site 12 , from 110 to at least 700 feet (34 to 214 meters), is dominated by the minerals palygorskite (attapulgite) and sepiolite. Associated with these unusual clays are numerous, thin varicolored layers composed of what appears to be altered volcanic tuff. It is possible that the entire barren clay section at Site 12 has been derived diagenetically from tuffaceous material. The considerable thickness of such a primary tuff could have resulted from slumping and current redistribution of palagnitic tuffs which are known to form by submarine volcanism (Nayudu, 1964). Sources of magnesium ions required to form the high magnesium clays are uncertain at this stage.

\section{Montmorillonitic Clays}

Clays of the montmorillonite type dominate the fine fraction of the sediment at Site 8 , along with small to moderate amounts of kaolinite. Site 9, on the Bermuda Rise, shows a dominance of montmorillonite throughout with moderate amounts of kaolinite at upper levels. Small amounts of montmorillonite occur in essentially calcareous biogenous oozes at Site 10 . Site 11 is conspicuously lacking in clay minerals, being essentially a pure calcareous pelagic ooze. Montmorillonite does not appear to be present at Site 12, where palygorskite and sepiolite dominate.

According to Nayudu (1964) montmorillonite is a principal post-eruptive product of palagonite. Peterson, et al. (1964) state that montmorillonite results from the relatively rapid diagenetic breakdown of basic volcanic debris. It is, therefore, considered that the bulk of the montmorillonite noted in sediments cored on Leg. 2 is probably of volcanic origin.

\section{Ash Beds and Altered Tuffs}

Fresh glass shards are rare in sediments cored on Leg 2 . On the other hand, there is evidence at some sites of beds of alterd ash. This is particularly true at Site 10, where volcanic minerals occur throughout calcareous biogenic ooze from a sediment depth of 1270 feet (417 meters) down to the igenous rock. The volcanic minerals in this case are in the form of fine-grained, generally opaque particles associated with zeolites and fresh, angular feldspar grains. They occur in dark layers and as disseminations throughout the ooze. Similar beds, both dark and light, occur at Sites 9 and 12 intercalated with thick, barren clay sequences. Particularly well-developed beds of altered ash, up to 20 centimeters thick, occur at the upper level of Pliocene sediments at Site 12. As stated above, it is considered 
likely that the massive clays of Sites 9 and 12 resulted from the post-depositional alteration of palagonite tuffs.

\section{Cristobalite-Bearing Sediments}

In addition to being the dominant constituent of cherts sampled on Leg 2 (see below), cristobalite occurs in locally large amounts in some unconsolidated and semi-indurated sediments at Sites 9, 10 and 12. As much as 90 per cent cristobalite occurs in the redbrown to brown-black sediments towards the bottom of the hole at Site 9. Locally as much as 12 per cent hematite forms the pigmentation in these shaly sediments. Cristobalite also occurs in the Miocene zeolitic clay section at Site 10 (see discussion above). It is also present in significant quantities with palygorskite and sepiolite at depth at Site 12. As discussed below, hydrothermal reactions may have contributed to the formation of this material. This possibility is strengthened by the occurrence of a dense, botryoidal manganese dioxide concretion in these sediments at Site 9 immediately overlying basalt, as well as by the presence of rhodochrosite and siderite in associated sediments (see below).

\section{Red and Brown Clays}

Typical deep-sea clays are rare in samples from Leg 2 drilling. Red-brown to brown-black Eocene to upper Cretaceous sediments sampled at Site 9 between a sediment depth of 2487 feet ( 760 meters) and basement at 2740 feet ( 836 meters) possibly fit the "red clay" category. These may correlate with what is a similar facies type in the Miocene at Site 10. Both examples are unusual in that they contain locally large proportions of cristobalite. Small to moderate amounts of siderite and rhodochrosite also occur at Site 9 along with up to 12 per cent hematite. As much as 40 per cent phillipsite is present in the red clay at Site 10 .

In the above two examples, it is considered likely that the red and brown clays are largely volcanogenic.

\section{Kaolinitic Clays}

Kaolinite, considered to be of terrigenous origin, occurs in sediments at Sites 8, 9 and 10 in minor to moderate quantities, and it is generally in association with montmorillonite. It also forms a significant component of the clay fraction at Site 12 from the surface down to a sediment depth of about 350 feet (107 meters). Detrital or aeolian sources from the North American and African continents may account for the presence of this clay mineral in the above sediments.

\section{Silty Clays and Fine Sands, Graded in Part}

Quartz silts and fine sands are significant sediments at Site 8, where the source is most probably nearby continental North America. Eocene graded beds of possible trubidity current origin were noted in a limited section of such sediments at Site 8 . Where sampled, the graded beds are composed of clay, silt and fine sand, mixed with size-graded siliceous microfossils. Beds are generally less than 20 centimeters thick. They show sharp basal contacts and gradational, laminated upper boundaries. They are separated by pink massive radiolarian mud units.

Associated with these possible turbidites are green silty spicule muds containing glauconite grains. This somewhat exotic sediment type invariably shows contorted slump-like sedimentary structures and occasionally contains clasts of buff radiolarian ooze. It is possible that these structures are the result of a turbidity current or mudflow type of origin. Certainly the mineralogy of the glauconite-bearing silt suggests an origin at a shallower depth, perhaps on the continental margin. However, it is considered very likely that the contortions observed in the cut core-along with admixtures of radiolarian ooze clasts-have been largely caused by the coring process.

\section{Channel Sands}

At Site 8, situated near the base of the continental rise, coarse sands and gravels of possibly Quaternary Age were recovered from the bumper subs after the drill-string was dismantled. These sands contain coarse pelecypod fragments and abundant heavy minerals. Echo-sounder profiles in the vicinity show numerous flat-floored channels or fan valleys which almost certainly connect with submarine canyons on the adjacent continental shelf. Such an origin would be plausible for the material at Site 8 .

\section{Cherts}

The dominant form of chert sampled on Leg 2 is a reddish-brown to dark gray-green flint-like rock with a distinct conchoidal fracture. This type of chert occurs at depth at Sites 8, 9, 10 and 12 and is of Eocene Age. Invariably, such cherts are associated with zones containing siliceous microfossils, dominantly Radiolaria. This is true even in cases where siliceous fossils are rare or absent in other parts of the record. Thin section studies of this type of chert show an oriented birefringent matrix containing ghosts of altered and replaced Radiolaria. X-ray diffraction studies (see Chapter 11) show a dominance of cristobalite in the mineralogy of these cherts in proportions generally in excess of 90 per cent.

\section{Silicified Quartz Silts}

At Site 8, a somewhat different type of cherty sediment, a cherty silty mudstone, occurs in association with radiolarian cherts. Generally this lithotype is of a light olive-green hue, and in some samples a crude layering is visible. In thin section, quartz silt is an important 
component in association with an oriented birefringent matrix, rare siliceous microfossils and rare glauconite grains. It is apparent that component minerals of this type of chert are exotic and possible originated as turbidites on the adjacent continental margin.

The notable fact concerning the above two types of cherty sediments is that they are all of Eocene Age. The uppermost layers of these silicified sediments appear to correlate with the seismic reflector known as Horizon A. The cherts are associated with what appears to have been an influx of siliceous organisms which occurred in Eocene times. They are occasionally, but not invariably, associated with volcanic material. The first of the above facts points to a relationship of chert to a period of increased silica productivity. The fact that volcanic debris is not always present indicates that a source of silica from the breakdown of volcanic minerals may not be plausible. The final conclusion at this stage is that the cherts were formed by the diagenetic dissolution of siliceous organisms with migration and redeposition of dissolved silica. The causes of such a localized process are not known at present.

\section{Dolomite}

Dolomite appears to be very significant at Site 10, where it occurs as well-formed rhombs up to 12 microns on an edge and scattered throughout a nannoplanktonforaminiferan chalk ooze. Calcareous microfossils in the ooze appear unaltered. However, in the lowermost 200 feet (61 meters) of the hole, the proportion of dolomite increases with depth up to an estimated 20 to 30 per cent. The presence of dolomite at this site correlates, at least superficially, with a considerable admixture of altered volcanogenic minerals. The greatest proportion of dolomite occurs a few feet above the igneous basement.

At Site 9, significant dolomite occurs as silt-sized irregular particles and rhombs within a foraminiferannannoplankton ooze of Quaternary Age. At this site, dolomite cuts out with depth at approximately the level at which calcareous ooze grades into essentially noncalcareous montmorillonitic clays.

At Site 12, at the deepest level cored, a proportion of about 20 per cent dolomite rhombs occurs in a thin layer in association with palygorskite and sepiolite clays and cristobalite. This dolomitic zone overlies an unsampled hard layer which was not sampled.

In all except the last example, dolomite is associated with obvious calcareous material which could provide a source of calcium. The source of magnesium, however, has not been isolated at present. Dolomite rhombs occurring in cores from the experimental Mohole (Fuller et al. 1966) were stated to have possibly originated from alteration of primary palagonite tuff.
Such an origin would be plausible for the dolomite encountered during Leg 2 drilling.

\section{Rhodochrosite}

Rhodochrosite is present in significant quantities in sediments at depth from Site 9. It occurs in association with a sparsely fossiliferous clay in the form of burrow fillings, faecal pellet replacements and silt-sized granules. The presence of rhodochrosite, according to Rex (Chapter 11), suggests significant hydrothermal reaction at Site 9.

\section{Siderite}

Siderite is a locally significant carbonate in sediments at Site 9, where it occurs in association with rhodochrosite in amounts as high as 23 per cent. It is present in minor amounts at depth at Site 9 in the cristobaliterich sediments. Siderite also occurs in minor quantities at Site 10 in the Miocene zeolitic clay zone and with clinoptilolite and dolomite in calcareous oozes at depth. Small quantities of siderite were noted in one sample from Site 12 in association with palygorskite, sepiolite and cristobalite.

The presence of siderite, frequently in association with rhodochrosite and cristobalite, suggests some form of hydrothermal alteration of pre-existing tuffs, as discussed earlier. Such a process appears to have been important at Site 9 and may also have occurred locally at Site 10.

\section{Rates of Sediment Accumulation}

The rates of sediment accumulation presented in this report are calculated using the absolute age assignments of Berggren (1969) to the paleontologic age of a horizon at a known depth in the sediment. No corrections have been applied for compaction with depth of burial (Hedberg, 1936; Hamilton, 1959), for missing intervals, or for local thickening and thinning caused by bottom currents. The values, therefore, do not represent a sedimentation rate, but a rate of accumulation based on the thickness of the final deposit. At Sites 10 and 11, sediment compaction appears insignificant from visual examination; but, at Site 9, the clay becomes shaly at the bottom of hole, suggesting that compaction may have a considerable effect on the sediment accumulation rate. At Sites 8 and 12 compaction appears to be slight.

Figure 2 is a graph of sediment age versus depth for all sites on Leg 2. The rate of accumulation of the carbonate-rich sediments near the crest of the MidAtlantic Ridge at Site 11 (1.4-1.6 cm/1000 years) is comparable to the Cretaceous and early Tertiary rates found on the lower flanks of the ridge at Site 10. The lower sedimentation rate at Site 10 from the upper Eocene to the Miocene-Pliocene boundary may have 


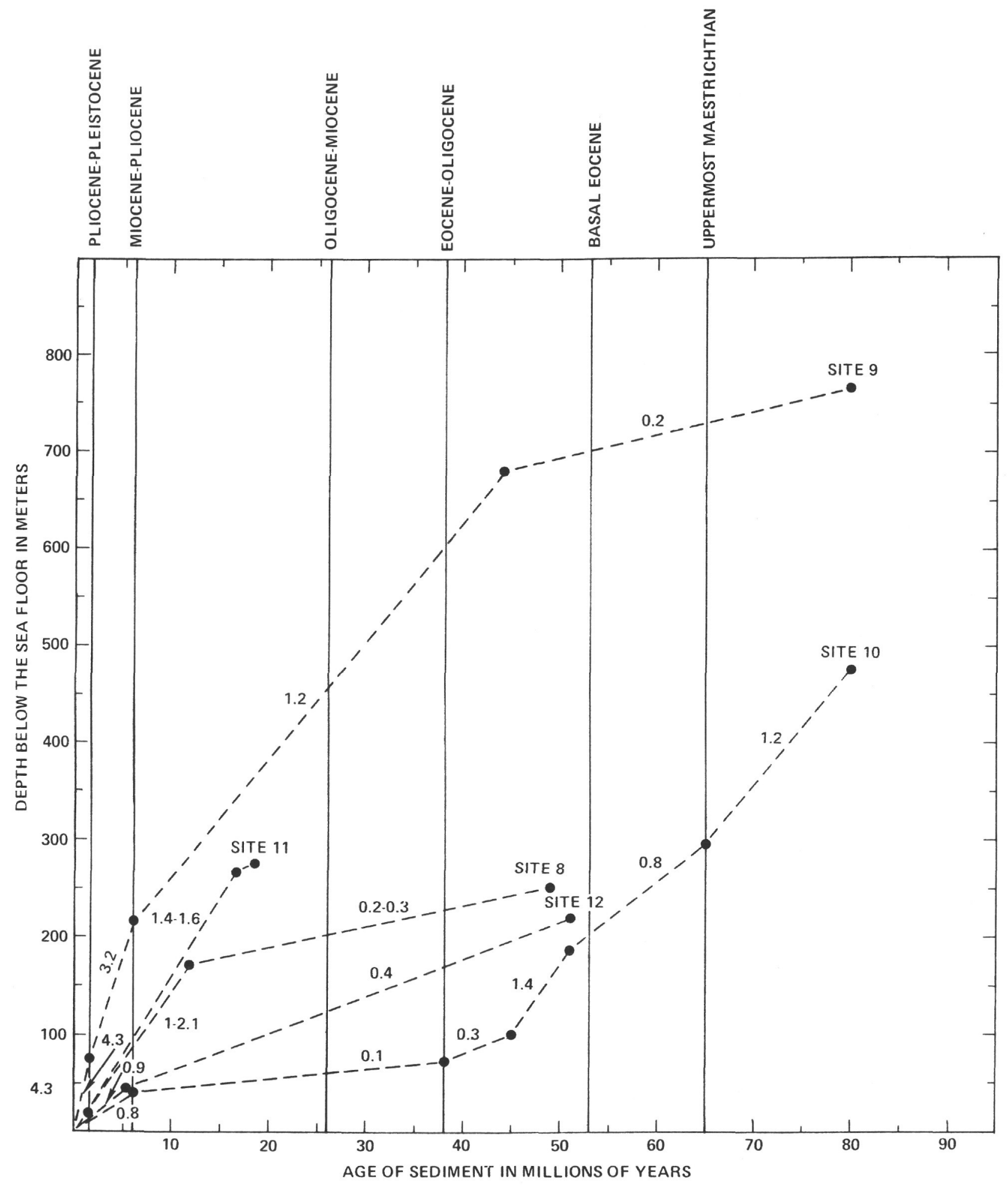

Figure 2. Sedimentation Rates at Sites drilled on Leg 2. 
resulted from a section which is probably missing in the lower and/or middle Miocene interval. In addition, clay intervals in the Miocene may partly account for the low rate. Note that the accumulation rate in the Pliocene and Quaternary sections at Site 10 is only slightly lower than that of the Cretaceous.

The rate of sediment accumulation at every site, except Site 11, is highest in the late Tertiary and Quaternary and is reduced appreciably in mid-and early Tertiary. Compaction may account for part of the apparently lower accumulation rate in the mid-and early Tertiary.

The rate of sediment accumulation at Site 9 is extremely high throughout post-Miocene times. Rates of 4.3 and $3.2 \mathrm{~cm} / 1000$ years in calcareous sediments are the highest determined from drilling on Leg 2, yet the water depth of 16,285 feet (4965 meters) is approximately at the depth of carbonate compensation in this area of the North Atlantic. The average accumulation rate at Site 9 of $1.2 \mathrm{~cm} / 1000$ years from the Eocene to the Pliocene includes faster accumulating calcareous sediments in the upper part (post Miocene) of a dominantly clay section.

In summary, calcareous sedimentation rates of 1 to $1.5 \mathrm{~cm} / 1000$ years are common on the Mid-Atlantic Ridge. In the late Cenozoic, high rates in calcareous sediments were measured at all sites lying above the depth of carbonate compensation. Tertiary and upper Cretaceous clay rates are relatively uniform, ranging from 0.2 to $0.4 \mathrm{~cm} / 1000$ years.

\section{Hydrothermal Mineralization}

At the base of the sediment section of Hole 9A, the iron oxide content increases markedly. By X-ray diffraction, 11.7 per cent of hematite was measured in one sample and in yet another sample about 10 per cent iron was determined. The increase in iron content is obvious from the remarkable change in color as the underlying igneous rock is approached. In addition, rhodochrosite, siderite and ferro-manganese nodular material are present.

The sediment is suggestive of material found at the crestal area of portions of the East Pacific Rise, and other crestal portions of the oceanic rise-rift systems (Bostram and Peterson, 1966, 1968, Bostram et al. (1969) in surface sediments. These modern sediments have been interpreted to result from precipitation from hydrothermal solutions ascending from magmatic events at depth.

It may be that the very iron rich sediments from Hole 9A have a similar origin. It should be noted that the sediments above igneous rock at Sites 10 and 11 do not show this increase in iron. Either such metal oxide precipitates are not entirely characteristic of the sediments first laid down on newly formed oceanic floor, or else some of the basal sediment has been lost beneath basement associated sills or lava flows.

Every gradation must exist between mineralization as a part of sedimentation over a magnetically active area and mineralization after deposition. These metaliferous sediments certainly warrant additional study to determine the nature and extent of mineralization.

\section{Diagenesis}

One of the outstanding features of the sediments recovered from the deep ocean basins is the abundance of authigenic minerals. Diagenetic silicates other than chert result in the greatest abundance from the alteration of volcanic debris. Carbonates included rhodochrosite, siderite and dolomite as products of recrystallization; silicates include zeolites and silica minerals, and various unusual clays. Sulfides are quite abundant and commonly replace organic structures. Clinoptilolite is the predominant zeolite in pre-Miocene sediment, whereas phillipsite dominates the post-Miocene zeolites. Textural studies may show some relationship between these minerals.

Reactions with the interstitial solutions follow, for the most part, rational trends. Where dolomite is common, magnesium has been somewhat depleted from the solutions. At Site 10, however, where dolomite is found with increasing abundance near the contact with igneous rock, the magnesium content of the solution is not appreciably depleted; the igenous rock may be serving as a more or less local source for magnesium.

The assemblage of fine-grained terrigenous clastics with radiolarian ooze and containing grey blebs of rhodochrosite in the Miocene and Eocene of the western Atlantic has its onshore equivalent. Rhodochrosite is the principal primary manganese ore of the Franciscan Formation of the California Coast Range. It is restricted to the radiolarian cherts (Taliaferro and Hudson, 1943). The mineralogy of the onshore Jurassic paragenetic assemblage of the California Coast Range matches the western Atlantic material so closely that more detailed comparison is recommended to improve our understanding of both the cherts and the rhodochrosite.

The abundance of palygorskite and sepiolite in the Miocene-Eocene of Site 12 is unique in deep sea sediments. Palygorskite has been reported from the Red Sea and Atlantic (Heezen et al., 1965; Hathaway and Schlee, 1966; Bonatti and Joensuu, 1965). In no previous case are there sediments where essentially the entire section is a bentonite that has been altered to palygorskite and sepiolite. The Site 12 assemblage, however, is similar to the extensive Miocene palygorskite 
and sepiolite derived from volcanic ash in Florida and Georgia (Gremillion, 1965).

Sepiolite and palygorskite are essentially magnesium silicates commonly occurring with dolomite in evaporite sediments. They also occur in association with hydrothermal alteration of serpentinites, but this later type of sepiolite does not seem similar to our deep water sediment case. There is no general world-wide evidence for an extensive magnesium enrichment of the oceans in middle Tertiary time to produce massive magnesium silicate deposits in the eastern Atlantic, so a more local origin of the magnesium-rich brines is suggested. Site 12 is at the foot of the African continental slope in the general vicinity of the Cape Verde Islands. For this reason, it might be possible that the high magnesium brines that altered the ash to palygorskite-sepiolite could be derived from near shore or a lagoonal concentration of sea water. The refluxion dolomitization concept of Adams and Rhodes (1960) for example suggests that concentrated sea waterderived magnesium-rich brines slowly flow back to the ocean through the continental shelf sediments. These dense refluxing brines might flow down dip in more permeable sediments and reach the base of the continental slope. This suggests the presence of evaporite brines of uncertain age onshore or near shore in Tertiary time along the African continental shelf in the Cape Verde Islands area.

A piercement salt dome province of probable upper Mesozoic Age occurs off the coast of Senegal and Gambia, only a short distance southeast of the Site 12 area (Aymé, 1965). Aymé (1965) points out that "there are a series of Mesozoic coastal basins stretching along the West African coast from Morocco and Spanish Sahara in the north to Gabon and Angola in the south. Because they have somewhat similar facies, they are often considered to be the outer rim of a large basin which is partially beneath the Atlantic Ocean. The existence westward from the African coast of possible marine Jurassic outcrops in the form of siliceous radiolarian cherts in the Cape Verde Islands adds weight to this argument, even though the mass of these islands is volcanic in origin." The salt domes of the Senegal-Gambia Basin extend at least 60 kilometers offshore and are developed well down the continental slope.

The Senegal-Gambia Basin matches the Cuba-Bahamian evaporite province of Mesozoic Age in the Bullard et al. (1965) reconstruction of Africa and North America before sea floor spreading. The Gabon-Congo Salt Basin matches the Sergipe Basin in Brazil further south both by Bullard's reconstruction and on the basis of geologic similarities (Belmonte, Hirtz, and Wenger, 1965). Further possible matches of evaporite basins on both sides of the Atlantic may be possible.
Furthermore, there are Caribbean anhydrite-gypsum deposits of probable Eocene Age on Jamaica, Hispanola, and northern Trinidad which should be tied into the Atlantic pattern.

Leg 1 drilling to the east of the Bahamas area showed a normal marine fauna in the western North Atlantic from the upper Jurassic to the present so that to some extent there must have been a normal open ocean in part of the western Atlantic at that time.

These observations suggest that the Mesozoic and lower Tertiary Atlantic may have been very similar to the Persian Gulf and Red Seas today. It is suggested that initially a Persian Gulf type of evaporite sea occurred with the Gulf of Mexico with its Luan Salt being deposited in one of the great evaporite embayments. As the Atlantic started rifting in Jurassic and Cretaceous time, several evaporite basins were formed along the shelves of the rifting ancestral basin and then split apart. By lower Tertiary time a series of peripheral Atlantic evaporite basins including the Senegal-Gambia, Gabon-Congo, the Brazilian, and the Caribbean had formed and were down warped and buried.

The above speculations are intended to advance the hypothesis that the Atlantic, the Red Sea and the Persian Gulf started out as similar features, but that the Atlantic has spread extensively, the Red Sea only slightly, and the Persian Gulf has only subsided a few hundred feet. This hypothesis suggests that additional drilling should be undertaken to outline those areas of old "Atlantic Gulf" that survive in the Atlantic Ocean. The possibility of a deep water petroleum province as large or larger than the Persian Gulf is too important to discard without evaluation. (Site 12 merits special attention both for special research on the existing samples and for a starting point for further deep sea drilling.)

Another alternative origin for the deep-sea palygorskitesepiolite would be some conditions whereby the silica content of the near bottom conditions is raised high enough so that magnesium could be stripped from sea water and precipitated directly as incipiently formed sepiolite, or other high-magnesian clays, to be subsequently recrystallized. The presence of volcanic debris could set the stage for high silica content in the bottom water. The presence of siliceous oozes attests the availability of silica in the surface waters. Palygorskite is also present in sediments on the western edge of the African continent (Wirth, 1968). Some of the deep water magnesian clays may be detrital, but the fine quality of the crystallinity suggests that they are largely grown, or at least recrystallized, in place.

The cherts found across the Atlantic consist predominantly of the mineral cristobalite. There is usually an 
associated silicate. In the western Atlantic this is usually the zeolite clinoptilolite. In Site 12 on the deep-water slope of the African continent, palygorskite and sepiolite are the accessory minerals. Radiolarians are common in the cherts and there is a tendency to call them radiolarian cherts. This term should be interpreted as without genetic implication, since the X-ray data suggest that the cristobalite is derived from mobilized silica of uncertain origin. It could result from devitrification of volcanic ash as well as from dissolution of biogenous opal. The common association of chert with zeolites as well as radiolarian tests makes a polygenetic origin probable. The abundance of radiolarian remains may well be linked to world-wide changes in volcanism tectonics and oceanic circulation.

\section{Sound Velocity in Sediments}

The transmission rate of sound through the cored sediment was measured through the core liner in the shipboard laboratory. The measurement is made across the diameter of the core, that is, approximately parallel to the bedding. The accuracy of the measurement is controlled to a large degree by the physical condition of the core by the time it reaches the shipboard laboratory. Another technique became available aboard the Glomar Challenger for measuring sound velocities in sediments. The seismic reflection profiler provided the reflection time to strong reflectors, such as Horizon A, or to basement and with the depth information provided by the drilling it became possible to calculate the average vertical in situ sound velocity through the sediment (Table 1 ).

The in situ average sound velocity in sediment cannot always be measured accurately because of uncertainties in the identification of the reflecting horizon from the drilling data. As Leg 1 scientists observed, Horizon A is composed of thin chert layers that decrease in thickness and frequency toward the top of the interval; and, it is uncertain at what level within this interval the chert is present in sufficient mass to return an adequate acoustic signal to be identified as Horizon A. At Site 8, the velocity calculation is made assuming the reflection to be from the top of the 57 -foot (17 meter) interval of chert cored.
Measurements of the average in situ sound velocity by this method will provide velocity data that can be of immense value to marine geophysicists and geologists in interpreting the vast amount of seismic data gathered from the deep oceans.

\section{Oldest Sediments}

As originally proposed, the old sediment objective was to be met at the completion of the Cape Verde site, which was primarily proposed for paleontologic interest. However, a second opportunity became available when it was decided that Leg 2 scientists should drill Site 8, which was omitted from the Leg 1 program because of time constraints.

At both places attempts to reach old sediments were thwarted by a combination of mechanical failures and the inability to penetrate the hard chert layers. At Sites 8 and 12, the oldest material recovered is of Eocene Age. Older (Cretaceous) sediments were recovered at Sites 9 and 10 where the chert is thinner and does not present such an obstacle to drilling.

The sediments found overlying the basement on the Mid-Atlantic Ridge (Sites 10 and 11) are very difficult to those in the deep basin (Site 9). At Sites 10 and 11, calcareous sediment is dominant throughout the section with the exception of thin layers of Miocene clay interbedded with the calcareous deposits at Site 10. Deepsea clays dominate the pre-Miocene sediment at Site 9 and directly overly basalt at the bottom of the hole. The occurrence of deep-sea clays overlying the basement at Site 9 indicates that the site was below the depth of the carbonate compensation at the time the basement complex was being formed or the surface waters did not support high organic productivity. In comparison, Site 10 on the lower flanks of the ridge, adjacent to the Sohm Abyssal Plain contains a rich, well preserved foraminiferal and coccolith fauna. The basement at Site 9 is presently 19,075 feet (5815 meters) below sea level and at Site 10 it is 16,964 feet (5171 meters); the present depth of carbonate compensation is about 16,100 feet (4900 meters) at this latitude in the North Atlantic (Berger, in press). There are several possible explanations for these observations.

TABLE 1

\begin{tabular}{|c|c|c|c|c|c|}
\hline Site & $\begin{array}{l}\text { Reflection } \\
\text { Time }\end{array}$ & $\begin{array}{l}\text { Drilling } \\
\text { Depth }\end{array}$ & $\begin{array}{c}\text { Hole } \\
\text { Inclination }\end{array}$ & $\begin{array}{l}\text { Vertical } \\
\text { Depth }\end{array}$ & $\begin{array}{l}\text { Sediment } \\
\text { Velocity }\end{array}$ \\
\hline 8 & $\begin{array}{c}\text { Horizon A (chert) } \\
0.32\end{array}$ & $\begin{array}{l}\text { top chert } \\
295 \text { meters }\end{array}$ & $20^{\circ}$ & 278 meters & $1735 \mathrm{~m} / \mathrm{sec}$ \\
\hline 9 & $\begin{array}{l}\text { Basement } \\
1.0\end{array}$ & 834 meters & $\sim 0^{\circ}$ & 384 meters & $1670 \mathrm{~m} / \mathrm{sec}$ \\
\hline 10 & $\begin{array}{l}\text { Basement } \\
0.50\end{array}$ & 459 meters & $\sim 0^{\circ}$ & 459 meters & $1830 \mathrm{~m} / \mathrm{sec}$ \\
\hline
\end{tabular}


1. The Mid-Atlantic Ridge either did not exist at the time the crust was formed at Site 9, or it was a subdued feature in comparison to the present ridge, and sedimentation initially occurred below the depth of carbonate compensation. The ridge developed as a significant topographic feature in the Late Cretaceous (Site 10). Essentially, then, this hypothesis claims that the deep basins were formed as deep basins and that the part of the ocean floor that is now the Mid-Atlantic Ridge was always part of the ridge.

2. The oldest sediments at Site 9 may be calcareous, lying beneath the iron-rich clay and igneous rock encountered by drilling. Soon after deposition of the calcareous sediments, the ocean floor must have subsided to below the depth of compensation, suggesting that the ridge was not such a positive feature in the Cretaceous as it is today.

3. The depth of carbonate compensation changed very significantly in the North Atlantic at the close of the Mesozoic Era. This infers a major change in the circulation pattern at that time, probably to the fundamental system active today.

4. Organic productivity in the ocean was very low in the area of Site 9 compared with the area of Site 10.

\section{Horizon A}

Horizon A (Ewing and Ewing, 1962) is an extensive acoustic reflector that has been mapped (Ewing et al., 1966) over a major part of the western North Atlantic between the Lesser Antilles and the Grand Banks. It has been traced westward to the lower continental rise and as far east as the lower western flank of the MidAtlantic Ridge. At a small area east of the Bahama Islands the reflector is exposed on the ocean floor, and piston cores taken at this location indicate that it is Upper Cretaceous trubidite (Ewing et al., 1966; Saito et al., 1966). The identification of the reflector as a turbidite suggested that the upper surface may be synchronous over large parts, if not all, of the mappable extent of Horizon $\mathrm{A}$, and that it was deposited as a flat, level surface. A dated, originally level surface extending over wide areas may be of immense value in studying the sedimentary and structural development of the ocean basin.

The scientists on Leg 1 of the Glomar Challenger cored Horizon A on the Bermuda Rise (Sites 6 and 7) and recovered mid-Eocene turbidites, commonly silicified and forming thin beds of chert. On Leg 2, Horizon A was found at Site 8 to be a mid-Eocene sequence of thin cherts interbedded with clay. The cherts are silicified turbidites and radiolarian muds. Reflectors, not easily correlated with Horizon A, identified at Sites 9 and 10 also appear to be Eocene cherts, but no allochthonous components were observed in these silicified radiolarian muds. Eocene cherts were also recovered from Site 12 in the eastern Atlantic Ocean, but considerable more geophysical and sampling data will be necessary before Horizon A can be correlated with a similar reflector in the eastern Atlantic.

Table 2 lists the ages assigned to the Tertiary cherts recovered on Legs 1 and 2 and the basis for the age assignment. At Sites 6,7 and 8, the age can be restricted to the mid-Eocene, but at Sites 9 and 12 the radiolarian fossils range through the entire Eocene. The Lower Eocene Age at Site 10 is well documented, but may not represent the uppermost chert horizon since the 70 meters immediately overlying this core was not sampled. The chert layers offered little resistance to the drill at this site, presumably because it is very thin, and thin layers of younger chert may have been penetrated in the overlying unsampled sediment. One piece of undated chert was cored in the Upper Cretaceous sediments at Site 9 , but based on the disturbed condition of the core it may have fallen to the bottom of the hole from the overlying Eocene chert layers.

From the drilling on Legs 1 and 2, Horizon A appears to be synchronous in the general concept of being no older or younger than Eocene, yet it seems to be considerably older to the south where cored at the Horizon A outcrop area. There are three possible explanations that need further investigation to verify:

1. The Eocene chert is not Horizon A, but merely a small interval above the stronger reflector, Horizon A.

2. Horizon A may be locally synchronous but diachronous in regional dimensions.

3. Horizon $\mathbf{A}$ is an Eocene chert but the piston core sampled from beneath this reflector.

At Sites 6, 7 and 8 the Eocene chert formed a substantial barrier to drilling, suggesting that the first explanation is an unlikely possibility.

\section{Sea Floor Spreading}

The magnetic symmetry about the axis of the midocean ridge in the North Atlantic between the equator and $30^{\circ}$ North cannot be recognized reliably beyond Heirtzler's anomaly 5, which was formed about 10 million years ago. Between anomaly 5 and the ridge axis, a distance varying between 75 and 150 kilometers, there is an insufficient thickness of sediment which is necessary to stabilize the bit before encountering hard rock (van Andel and Bowin, 1968). It was, therefore, evident that testing the concept of sea-floor spreading with the drill would have to be undertaken beyond the correlative and symmetrical magnetic anomaly patterns. Sites were selected with the intention of establishing 
TABLE 2.

Ages Assigned To Tertiary Cherts At Sites Drilled In The N. Atlantic.

\begin{tabular}{|c|c|c|c|}
\hline \multirow[t]{2}{*}{ Hole } & Interval & Age & Fossil \\
\hline & meters feet & & \\
\hline 8 and $8 A$ & $\begin{array}{l}913-1000 \\
8 \mathrm{~A} / 1-8 \mathrm{~A} / 3\end{array}$ & Middle Eocene & $\begin{array}{l}\text { Sethamphora mongolfieri } \\
\text { Podocyrtis papalis } \\
\text { Lynchocanium bellum } \\
\text { Dictyophimus babylonis }\end{array}$ \\
\hline 9 and $9 \mathrm{~A}$ & 2226 & Eocene & $\begin{array}{l}\text { Sethamphora mongolfieri } \\
\text { Podocyrtis papalis }\end{array}$ \\
\hline 10 & $548-78$ & $\begin{array}{l}\text { Lower Eocene } \\
\text { ( } 70 \text { meter interval } \\
\text { above, not cored) }\end{array}$ & $\begin{array}{l}\text { Lychnocanium bellum } \\
\text { Sethamphora mongolfieri } \\
\text { Podocyrtis papalis } \\
\text { Anthocyrtidum hispidium } \\
\text { Discoaster lodoensis } \\
\text { D. barbadiensis } \\
\text { D. kupperi } \\
\text { Chiasmolithus grandis } \\
\text { Sphenolithus radians } \\
\text { Cruciplacolithus staurian }\end{array}$ \\
\hline 12 & $\begin{array}{l}530 \\
12 \mathrm{~B} / 2\end{array}$ & Eocene & Anthocyrtidium hispidium \\
\hline 6 & & Middle Eocene & $\begin{array}{l}\text { Lithocyclia ocellus } \\
\text { Eusyringium fistuligerum } \\
\text { Chiasmolithus expansus } \\
\text { C. gigas } \\
\text { C. grandis } \\
\text { C. solitus } \\
\text { C. staurion } \\
\text { Discoaster barbadensis } \\
\text { Sphenolithus furcatolithoides }\end{array}$ \\
\hline 7 and $7 \mathrm{~A}$ & $\begin{array}{l}235 \\
7 / 2\end{array}$ & Middle Eocene & $\begin{array}{l}\text { Chiasmolithus expansus } \\
\text { C. gigas } \\
\text { C. grandis } \\
\text { Chiphragmalithus cristatus } \\
\text { Discoaster elegans } \\
\text { Reticulofenestra umbilica } \\
\text { Sethamphora mongolfieri } \\
\text { Anthocyrtidium hispidium } \\
\text { Phormocyrtis striata } \\
\text { Dictyophimus babylonis }\end{array}$ \\
\hline
\end{tabular}


whether or not the sediments immediately overlying the acoustic basement increase in age away from the ridge axis. It is assumed on the basis of limited dredging in fracture zones where the rock beneath the acoustic basement reflector is presumably exposed (van Andel and Bowin, 1968) that no significant amount of sediment is buried within the basement complex of the Mid-Atlantic Ridge.

A number of mechanical failures aboard the vessel reduced the time available for drilling to such an extent that not all the program proposed for the testing of sea-floor spreading in the North Atlantic could be completed. At three sites, igneous rocks were reached at a depth which corresponded closely with acoustic basement, assuming a generally acceptable value for sound velocity in sediments.

Some of the igneous rock may have been emplaced as sills rather than flows on the ocean floor, based on the presence of diabase, metamorphism of sediments adjacent to the igneous rock (marble-like rock at Site 10) and glasses that intruded the overlying sediments. At Site 11 , a thin layer of baked sediment was found between two pieces of basalt. The ages assigned to the sediment immediately overlying the basement rocks is, therefore, older than the igneous rocks where sills are indicated. However, as mentioned above, the depth at which igneous rock was first encountered corresponds to acoustic basement within the acceptable sediment velocity range of 1670 to $1830 \mathrm{~m} / \mathrm{sec}$. It appears from these observations that the upper part of the basement complex is composed of interbedded flows, sills and sediments.

The bulk of the basement layer is probably formed in a narrow zone, the median valley, of the axial region of the spreading ridge. As the sea-floor spreading process continued to remove the accumulation of igneous rock away from the center of extrusion, flows would become less frequent-as only the more extensive flows would reach far from the source. Eventually the crest would be sufficiently remote from the axial region so that significant thickness of sediment would accumulate in the lengthened time interval between flows. The density difference between young pelagic sediments and the overlying sea water is so slight that the igneous material would tend to follow the basement-sediment contact rather than the sediment-water interface. Consequently, when extensive igneous extrusions would flow away from the source area to the region of older rock covered with thin sediment, they would plow through the sediment as sills. Baked sediment with glass veins would be expected at the contact.
It is difficult to estimate the amount of sediment buried by these basement associated sills. It if is assumed that the rate of sediment accumulation in the crestal region may be represented by the figure determined for the basal sediments at Site $11(1.5 \mathrm{~cm} / 1000$ years), then 30 meters of sediment would have accumulated over a period of two million years. During this time interval, spreading would have shifted the crust 20 kilometers away from the ridge axis, assuming a spreading rate of 1 centimeter a year (see spreading rates). Based on the wave length of the present axial magnetic anomaly (less than 50 kilometers) and the width of the active seismic zone along the crest of the ridge (less than 50 kilometers), which may be indicators of the width of the zone of igneous and volcanic activity, a location some 20 kilometers on either side of the ridge axis would receive fewer igneous contributions than the crest; and, at 40 kilometers ( 4 million years) it would probably not receive any at all. It may, therefore, be reasoned that in areas of high sedimentation rate sills rather than flows found interbedded with sediments are a natural consequence of the sea-floor spreading process, and the amount of sediment lying beneath the shallowest sill represents a relatively insignificant time interval. Igneous activity not related to the ridge crest source may cover a substantial amount of sediment.

The age of the sediments associated with the basement in Sites 10 and 11 is well established and the average rate of sea-floor spreading from the ridge axis to Site 11 and from Site 11 to Site 10 is well determined at 1.0 and $1.2 \mathrm{~cm} / \mathrm{yr}$, respectively. This rate corresponds closely with the spreading rate of $1.25 \mathrm{~cm} / \mathrm{yr}$ determined for the late Cenozoic from magnetic studies by Phillips (1967). The age of the sediment of the lowest 230 feet (70 meters) at Site 9 cannot be accurately established, but the oldest sediment that can be reliably dated is Santonian (late Cretaceous). The sediment accumulation rate between the Santonian and the Eocene is $0.2 \mathrm{~cm} / 1000 \mathrm{yrs}$; and, if this rate is applied to the lowest undated interval, the oldest sediments should be 120 million years old or Barremian (middle Lower Cretaceous), neglecting corrections for compaction. If this is an acceptable age, then the average spreading rate from the Barremian to the early Campanian would have been $1.4 \mathrm{~cm} / \mathrm{yr}$ or slightly less if compaction of the sediment is considered in the above extrapolation. On the other hand, if the Mesozoic spreading rate was approximately the same as the Cenozoic, then by projecting the spreading rate to the intersection with the distance from the ridge axis to the continental margin (2400 kilometers) then the age would be 200 million years; a reasonable age based on other paleomagnetic (Phillips, 1967) and geologic evidence. 


\section{REFERENCES}

Adams, J. E. and Rhodes, M. L., 1960. Dolomitization by seepage refluxion. Bull. Am. Assoc. Petrol. Geologists. 44, 1912.

Ayme, J. M., 1965. Senegal salt basin. In Salt Basins around Africa. Inst. of Petrol. Symposium 3 March 1965, Elsevier. 83.

Belmonte, Y., Hirtz, P. and Wenger, R., 1965. Salt basins of the Gabon and Congo (Brassaville). In Salt Basins around Africa. Inst. of Petrol. Symposium 3 March 1965, Elsevier. 55.

Berger, W. H., 1969. Biogenous deep sea sediments: fractionation by deep-sea circulation. (In press) $J$. Sediment Petrol.

Berggren, W. A., 1969. Rates of evolution in some Cenozoic planktonic foraminifera. Micropaleontology. 15, 3, 351 .

Bonatti, E. and Joensuu, O., 1968. Palygorskite from Atlantic deep-sea sediments. Am. Mineralogist. 53, 975.

Bostrom, K., Peterson, M. N. A., 1966. Precipitates from hydrothermal exhalations on the East Pacific Rise. Econ. Geol. 61, 1258.

. 1968. The origin of aluminum poor sediments in areas of high heat flow on the East Pacific Rise.

Bostrom, K., Peterson, M. N. A., Joensuu, O. and Fisher, D., 1969. Aluminum-poor ferromanganoan sediments on active oceanic ridges. J. Geophys. Res. 74, 3261 .

Bullard, E., 1969. Origin of the oceans. Sci. Am. 221, 66.

Bullard, E. C., Everett, J. E. and Smith, A. G., 1965. The fit of the continents around the Atlantic. In A Symposium on Continental Drift. Phil. Trans. Roy. Soc. London. 258, 41.

Ewing, J. I. and Ewing, M., 1962. Reflection profiling in and around the Puerto Rico Trench. J. Geophys. Res. 67, 4729.

Ewing, J. I., Worzel, J. L., Ewing, M. and Windisch, C., 1966. Age of Horizon A and the oldest Atlantic sediments. Science. 154, 1125.
Fuller, M. D., Harrison, C. G. A. and Nayudu, Y. R., 1966. Magnetic and petralogic studies of sediment found above basalt in experimental Mohole core EM7. Bull. Am. Assoc. Petrol. Geologists. 50, 566.

Gremillion, L. R., 1965. Origin of attapulgite in the Miocene strata of Florida and Georgia. (Ph. D. Thesis, Dept. Geology, Florida State University, $96 \mathrm{pp}$.

Hamilton, E. L., 1959. Thickness and consolidation of deep-sea sediments. Bull. Geol. Soc. Am. 70, 1399.

Hathaway, J. C. and Schlee, J. S., 1968. Stratigraphy and mineralogy of sediments cored off Northern Florida (abstract). Geol. Soc. Am. Spec. Papers, $101,437$.

Hedberg, H. D., 1936. The gravitational composition of clays and shales. Am. J. Sci. 231, 241.

Heezen, B. C., Nesteroff, W. D., Oberlin, A. and Sabatier, M. G., 1965. Decouverte d'attapulgite dans les sediments profounds du golfe d'Aden et de la mer Rouge. Compt. Rend. Sol. Geol. Paris. 260, 5819.

Nayudu, Y. R., 1964. Palagonite tuffs (hyaloclastites) and the products of post-eruptive processes. Bull. Volcanol. 27, 391.

Peterson, M. N. A. and Griffin, J. J., 1964. Volcanism and clay minerals in the southeastern Pacific. $J$. Marine Res. 22, 13.

Phillips, J., 1967. Magnetic anomalies over the MidAtlantic Ridge near $27^{\circ}$ N. Science. $157,920$.

Saito, T., Burkle, L. and Ewing, M., 1966. Lithology and Paleontology of the reflective layer Horizon A. Science. 154, 1173.

Taliaferro, N. L. and Hudson, F. S., 1943. Genesis of the manganese deposits of the Coast Ranges of California. In Manganese in California. Calif. Dept. Nat. Resources, Div. Mines Spec. Rept. (125), 217.

Van Andel, T. H. and Bowin, C. O., 1968. MidAtlantic Ridge between $22^{\circ}$ and $23^{\circ}$ North Latitude and the tectonics of mid-ocean rises. J. Geophys. Res. 73, 4, 1279.

Wirth, L., 1968. Attapulgites du Sénégal Occidental. Laboratoire Geologie Université Dakar, Rapport No. 26. 